\title{
CULTURAL ATTITUDES CONDUCIVE TO THE IMPLEMENTATION OF CORPORATE SOCIAL RESPONSIBILITY ACTIVITIES IN ENTERPRISES
}

\author{
Dorota CHMIELEWSKA-MUCIEK ${ }^{1 *}$, Bartłomiej ZINCZUK ${ }^{2}$ \\ ${ }^{1}$ Maria Curie-Skłodowska University, Faculty of Economics, Lublin, Poland; \\ dorota.chmielewska@umcs.lublin.pl, ORCID: 0000-0001-9166-7983 \\ ${ }^{2}$ Maria Curie-Skłodowska University, Faculty of Economics, Lublin, Poland; \\ b.zinczuk@poczta.umcs.lublin.pl, ORCID: 0000-0003-2808-8510 \\ * Correspondence author
}

Purpose: The aim of the research was to determine the cultural attitudes conducive to CSR implementation in an enterprise, and then to verify their occurrence in enterprises implementing CSR.

Methodology: The research used the diagnostic survey method. The research tool used by the Authors of the article was a questionnaire allowing the verification of the occurrence of 12 cultural attitudes conducive to CSR in the surveyed enterprises. The research covered 234 enterprises on the territory of Poland, which declared CSR activities.

Findings: As a result of the research, all the cultural attitudes were verified and their occurrence was assessed with a medium and low intensity, most often these are attitudes describing managers than employees. Cultural attitudes conducive to the implementation of CSR, although they are noticeable in the researched enterprises, to a small extent, support the implementation of CSR activities.

Research limitations: Conducting research in enterprises outside the territory of Poland and comparing it with national ones could significantly increase the scientific value of the article.

Practical implications: Research brings new knowledge and can be used by management in their practical activities.

Social implications: The results of the research increase the level of knowledge on the issue of cultural attitudes conducive to CSR implementation in enterprises.

Originality: The authors identified cultural attitudes conducive to the implementation of CSR in the enterprise, verified their occurrence in the surveyed enterprises and assessed whether the cultural attitudes verified by them are conducive to the implementation of CSR activities in the enterprise.

Keywords: CSR, CSR determinants, cultural attitudes, small and medium enterprises.

Category of the paper: Research paper. 


\section{Introduction}

Modern enterprises operate in a network of mutual interactions with various market participants, taking responsibility for the quality of goods and services produced, as well as for the shape and course of social relations established with various stakeholder groups. Respect for and observance of ethical and legal principles by modern enterprises is considered in the public opinion as obligatory actions, however, the nature and speed of the changes taking place in the modern economy determines that enterprises pay more attention to the problem of social responsibility. In the face of dynamic social, cultural and economic changes taking place in the business environment, the concept of corporate social responsibility is becoming more and more important, which is reflected in an increasing amount of scientific research and in management practice.

One of the areas of research work on socially responsible activities carried out by enterprises is on the conditions conducive to their implementation. Some literature studies present a comprehensive account of various conditions conducive to the implementation of Corporate Social Responsibility (CSR) with their division into selected groups (Kaźmierczak, 2017; Filek, 2008), while others are devoted only to those from the enterprise itself (Rudnicka, 2011; Rahbek, 2016; Terec-Vlad, 2016).

Despite specific factors conditioning the implementation of CSR by enterprises (the authors reviewed the literature on this subject in the next section), it is worth noting that little attention is paid to cultural attitudes in the literature. Cultural attitudes are worth attention because the introduction and implementation of CSR in the enterprise, despite, among other things, an appropriate strategy, structure or financial situation, will encounter a significant barrier if the attitudes of management and employees are not be conducive to supporting CSR activities. Collier and Esteban (2007, p. 19-33) noted that it is the employees' responsibility to introduce an ethical organisational culture based on CSR principles, and achieving this depends on their willingness to cooperate, their openness (Morsing, 2006), creativity (Ejdys, Gulc, 2015, pp. 103-151) and commitment (McShane, Cunningham, 2012, pp. 81-115). The attitude of the management is also crucial. The essence of CSR is interpreted as an expression of values recognised by individual managers and the result of managing decision-making processes (Jaakson, Vadi, Tamm, 2009). These values manifest themselves in such attitudes as: concern for employees (Żemigała, 2007), participation (Bartkowiak, 2001), trust (Głuszek, 2010). Mohelska and Sokolova, among the attitudes conducive to CSR implementation also strongly emphasize an honest and open attitude towards external stakeholders (2011, pp. 853-865).

There is a large number of cultural attitudes mentioned in the literature, some of which are mentioned more often than others, but they are not systematized. Most often, cultural attitudes are discussed in the context of various reflections on CSR or they are part of the final conclusion. The research gap identified by the authors of the article results from recognizing 
the limited number of studies on the issue of cultural attitudes conducive to the implementation of corporate social responsibility activities in enterprises.

\section{Factors determining the implementation of CSR by enterprises}

Effective introduction and implementation of any management concept is conditioned by many factors. This also applies to the notion of corporate social responsibility (CSR), which is defined as "commitment to improve community well-being through discretionary business practices and contributions of corporate resources" (Kotler, Lee, 2005, p. 3). J. Adamczyk defines CSR as "an obligation to conduct business transparently and ethically according to the principles of sustainable development and in pursuit of social welfare, taking into account the expectations of stakeholders in accordance with the law and norms of behaviour" (Adamczyk, 2009, p. 10). R.W. Griffin and R.J. Ebert point out that corporate social responsibility obliges organisations to maintain a balance in their actions towards groups in their environment, including customers, employees, investors and local communities (Griffin, Ebert, 2006, p. 68). Corporate social responsibility must be seen as a contemporary challenge to solve the complex economic, environmental and social problems resulting from the change in the economic, political, technical and technological orientation of modern organizations (Bartkowiak et al., 2016, p. 9).

Some conditions are external in nature, over which the enterprise either has no influence (macro-environment) or to some extent controls and shapes them (micro-environment). J. Filek includes the socio-economic situation of the country and the moral awareness of the society among the factors connected with macro-environment (Filek, 2008, p. 63). Macroeconomic factors include the labour market and the standard of living of people in economic, technological and administrative terms (Bartkowiak, 2011, p. 125; Kaźmierczak, 2017, pp. 81-89; Wilewska, 2011, p. 199), to which the enterprise can only adapt.

The microenvironmental elements shaping CSR are described in detail in the literature and are focused mainly on external stakeholders, who are one of the main target groups of the enterprise's activities within the framework of CSR implementation (Doktór, 2005, pp. 34-37; Geryk, 2012, p. 37; Wołoszyn, Ratajczak, 2010, pp. 95-102). E. Pedersen and others also write about stakeholders, mentioning the uncertainty of the environment and national culture as elements of the micro-environment (Pedersen et al., 2016, pp. 267-284). G. Bartkowiak, when analysing determinants coming from the micro-environment of enterprises, also mentions relations with investors, suppliers and customers (Bartkowiak, 2011, p. 125).

Internal factors constitute an important group of factors influencing the implementation of CSR by enterprises. As particularly important for the implementation of CSR, R. Slack and others mention communication in the organisation; organisational culture, the level of 
embedding CSR in the organisation and relations between CSR and business strategies (Slack et al., 2015, pp. 537-548). The condition for successful CSR implementation is the existence of an innovative organisational culture and support for the introduction of its principles to the corporate strategy (Mohelska, Sokolova, 2017, p. 857). Bem (2008), Wołczek (2011), Gazzola and Colombo (2014) write about the importance of the strategy in CSR implementation. Transformational leadership is also related to the implementation of corporate social responsibility (De Lacerda, 2010; Du et al., 2013; Groves, Larocca, 2011).

Factors determining the introduction and implementation of CSR intertwine to create a system of interconnected factors of different nature and strength of impact of dependent factors. It is specific for each enterprise, hence the CSR measures adopted are an expression of the enterprise's individual approach to the issue of social responsibility. Due to the fact that the enterprise has only an influence on the internal factors determining CSR, they are a particular point of interest for managers, as well as researchers. Most often, these considerations focus on organisational culture (Galbreath, 2010; Ganescu, Gangone, 2017; Rudnicka, 2012), strategy (Chandler, 2014; Malara, Kroik, 2012; Vitolla et al., 2017), human capital (Borkowska, 2005; Kaźmierczak, 2015; Zieliński, 2015) and financial activity (Bednarska-Olejniczak, 2017; Ciechan-Kujawa, 2013; Filek, 2008). They focus much less on the internal factor - the attitude of employees towards CSR. Introduction and implementation of CSR in the enterprise, despite the appropriate strategy, culture, finances, will meet a barrier if the attitude of management and employees will not be conducive to CSR.

\section{Cultural attitudes conductive to the implementation of CSR in enterprises}

According to P.G. Zimbardo and M.R. Leippe, a cultural attitude is an "evaluating attitude towards any object" (Zimbardo, Leippe, 2004, p. 51). Expressed through "positive or negative attitude towards an object, notion or situation, as well as readiness to react in a predetermined way to these objects, notions or situations" (Hilgard, 1971, p. 73). A person's attitude expresses what he or she likes and dislikes, interest and aversion, the way of evaluating relations with others as well as between a person and a specific object. The subject may be "the organisation as a whole, its management, direct superiors, employees or their specific groups, and finally the tasks performed or certain types of tasks" (Koźmiński, Jemielniak, 2008, p. 184). The CSR concept may also be subject of evaluation. The attitude of employees towards it may be negative or positive, and consequently, the readiness of employees to introduce and implement it may be either inhibitory or conducive. Hence, from the point of view of effective implementation of CSR, it is important to determine the attitudes conducive to its implementation. 
Among the attitudes conducive to the implementation of CSR by enterprises, the following are mentioned: responsibility for the effects of the implemented activities, reliable communication with the environment, care for environmental protection, compliance with agreements and obligations, promotion of ethical norms and behaviours among stakeholders (Rozkwitalska, 2006, p. 44). Enterprises using CSR are characterised by the creative attitude of employees, their willingness to develop and experiment, teamwork, ways of communication, friendly relations and openness (Walkowiak, 2009, p. 116). In K. Klimkiewicz's opinion, the attitudes conducive to CSR are openness, tolerance and dialogue in the enterprise, freedom in decision-making, focus on argumentation and not on power, involvement of employees, allowance for the implementation of individual values (Klimkiewicz, 2011, pp. 143-144). Some of the above attitudes illustrate the attitude of employees, while others illustrate the attitude of the management towards CSR. Some point to relationships with people, others to employee characteristics, organisational solutions and values. The list of attitudes conducive to CSR implementation, based on the review of literature and the results of the research, is presented in Table 1. They were the basis for empirical research.

Table 1.

Cultural attitudes conducive to the implementation of CSR

\begin{tabular}{|c|c|}
\hline $\begin{array}{c}\text { Attitudes conducive to } \\
\text { CSR }\end{array}$ & Justification \\
\hline $\begin{array}{l}\text { Management } \\
\text { commitment }\end{array}$ & $\begin{array}{l}\text { The instrumental role of the management in formulating the CSR policy } \\
\text { presented the CSR as an expression of the values of individual managers and the } \\
\text { result of management of decision-making processes (Jaakson et al., 2009, p. 7). }\end{array}$ \\
\hline Egalitarianism & $\begin{array}{l}\text { Subordinates expect to consult their superiors when making decisions. A superior } \\
\text { is not a person who imposes solutions on employees, but a master or a trainer. } \\
\text { He/she should give guidance, set general management objectives, but should not } \\
\text { set out specific action plans and programmes (Wolniak, 2015, p. 349). }\end{array}$ \\
\hline Care for employees & $\begin{array}{l}\text { Management applies human resources management practices that promote } \\
\text { personal and professional development, diversity at all levels and empowerment, } \\
\text { respects employees as valuable business partners, respects their rights to } \\
\text { employment, competitive salaries and benefits, and a safe, family-friendly work } \\
\text { environment (Żemigała, 2007, p. 114). }\end{array}$ \\
\hline $\begin{array}{l}\text { Appreciation of } \\
\text { employees }\end{array}$ & $\begin{array}{l}\text { Employees play a very important role in the success of the enterprise. Not only do } \\
\text { they belong to the internal stakeholders of the enterprise, but they also build } \\
\text { appropriate relations with external stakeholders, they are members of local } \\
\text { communities and create the image of the company (Ratajczak et al., 2012, } \\
\text { p. 382). }\end{array}$ \\
\hline Employee involvement & $\begin{array}{l}\text { CSR implementation is rarely successful if it is imposed from above, by force. } \\
\text { In this case, the employees simply pretend to be socially responsible. Only the } \\
\text { conviction that social responsibility is important makes people be really involved } \\
\text { in it (Walkowiak, 2009, p. 349). }\end{array}$ \\
\hline Employee creativity & $\begin{array}{l}\text { Propagation and dissemination of behaviours aimed at environmental protection, } \\
\text { as well as internal and external social relations among employees may be a source } \\
\text { of creative behaviours influencing innovative solutions (Ejdys, Gulc, 2015, } \\
\text { p. 112). }\end{array}$ \\
\hline Flexibility of employees & $\begin{array}{l}\text { Enterprises applying CSR operate in conditions of variable demand from } \\
\text { customers, and the speed of response depends on the flexibility of staff and their } \\
\text { willingness to cooperate (Bartkowiak, 2011, pp. 22-23). }\end{array}$ \\
\hline
\end{tabular}


Cont. table 1.

\begin{tabular}{|l|l|}
\hline $\begin{array}{l}\text { Openness in } \\
\text { communication }\end{array}$ & $\begin{array}{l}\text { In the case of internal stakeholders, communication is an essential element of } \\
\text { building relations with them. An example are employees who, thanks to two-way } \\
\text { communication, feel that decisions made in the enterprise are the result of } \\
\text { consultations conducted with the whole team, which makes them more willing to } \\
\text { comply with the recommendations and it is easier for them to adapt to new } \\
\text { conditions, and often they themselves are the initiators of socially responsible } \\
\text { actions. Additionally, communicating about social responsibility (messages } \\
\text { created by the organisation and distributed by it) has a positive impact on the } \\
\text { identification of employees with the workplace (Morsing, 2006, p. 171). }\end{array}$ \\
\hline $\begin{array}{l}\text { Orientation towards } \\
\text { external stakeholders }\end{array}$ & $\begin{array}{l}\text { CSR is a stakeholder-oriented concept. For this reason, the company not only } \\
\text { takes responsibility for achieving its goals, but also for stakeholder expectations. } \\
\text { We should aim for a situation where there are no losers. Knowledge of } \\
\text { stakeholders and their interests is essential to ensure mutual satisfaction. } \\
\text { The ideal situation is equality between the actions supported by the company's } \\
\text { management and those required by stakeholders. In this sense, implementation is } \\
\text { understood as changing the business and social environment of the company in } \\
\text { accordance with the aforementioned stakeholders' interests (Mohelska, Sokolova } \\
\text { 2017, p. 885) }\end{array}$ \\
\hline Innovation & $\begin{array}{l}\text { Investing in socially responsible activities can provide internal benefits by } \\
\text { helping companies to develop new resources and capabilities that are difficult to } \\
\text { imitate or to substitute (Branco, Rodrigues, 2006, p. 111-132). }\end{array}$ \\
\hline Learning orientation & $\begin{array}{l}\text { The association between CSR and intellectual capital can enhance the competitive } \\
\text { advantage since CSR deeply rooted in this kind of capital can help developing a } \\
\text { resource that is rare, non substitutable and hard to imitate (Albertini, 2015, p. 1). }\end{array}$ \\
\hline Cooperation & $\begin{array}{l}\text { A company becomes socially responsible when the mutual benefits of those who } \\
\text { jointly build its success are visible: employees, customers, organisations with } \\
\text { which it cooperates (Kuraszko, Rok, 2007, pp. 5-6). }\end{array}$ \\
\hline
\end{tabular}

Source: own study.

\section{Research methodology}

The aim of the article is to show cultural attitudes conducive to the implementation of CSR in enterprises. The article is theoretical and empirical in nature. In the article there are considerations around the main question adopted in the work: What cultural attitudes are conducive to the implementation of CSR in enterprises. The intent of the research was to identify cultural attitudes conducive to the implementation of CSR, and then to verify their occurrence in enterprises implementing CSR. The main objective of the work was to define attitudes conducive to the implementation of CSR in enterprises. Within the framework of the main objective, specific epistemological and pragmatic objectives were achieved, which consisted in:

- defining cultural attitudes characteristic for managers and employees in enterprises declaring the implementation of CSR activities,

- verifying cultural attitudes in enterprises implementing CSR,

- attempting to assess whether verified cultural attitudes are conducive to the implementation of CSR activities. 
The subject of the research was the cultural attitudes conducive to the implementation of CSR in enterprises and the object of the research were enterprises declaring the implementation of CSR activities. The research covered 234 small and medium enterprises declaring the implementation of CSR activities. There were 150 small enterprises (employing up to 49 persons) and 84 medium-sized enterprises (employing between 50 and 249 employees). The majority of the analysed enterprises conducted trade and service activities (62\%), while the remaining 88 enterprises conducted production activity. The research was conducted in enterprises located in Poland in 2017.

A research questionnaire was used to carry out the research. The questionnaire consists of demographics and 36 questions enabling verification of the occurrence of 12 cultural attitudes in the surveyed enterprises that are conducive to the implementation of CSR. Questions were answered by 234 managers (one from each enterprise). Respondents replied to the questions contained in the questionnaire using a 5-point Likert scale. Particular assessments indicated the way in which the respondents perceived the occurrence of the analysed attitude in the enterprise, where 1 meant "I strongly disagree", 2 - "I rather disagree", 3 - "a neutral position", 4 - "I rather agree", and 5 - "I strongly agree".

Arithmetic mean was used to diagnose and present the research results. The interpretation was based on the following ranges which demonstrate the scale of the occurrence of the analysed attitude and its aspects: 5-4,76 - very large, 4,75-4,26 - large, 4,25-3,76 - medium, 3,75-3,26 - small, 3,25-3,00 - very small. An arithmetic mean below 3.00 indicates no attitude.

\section{Research results}

On the basis of the conducted research it can be stated that the following cultural attitudes are present in enterprises implementing CSR:

- care for employees - 3.94,

- orientation towards external stakeholders - 3.91,

- employee appreciation - 3.86,

- management's involvement in CSR - 3.85,

- employee involvement - 3.83,

- creativity of employees -3.8 ,

- openness in communication -3.72,

- egalitarianism-3.6,

- cooperation - 3.58,

- flexibility of employees - 3.56,

- learning orientation - 3.49,

- innovativeness of employees -3.45 . 


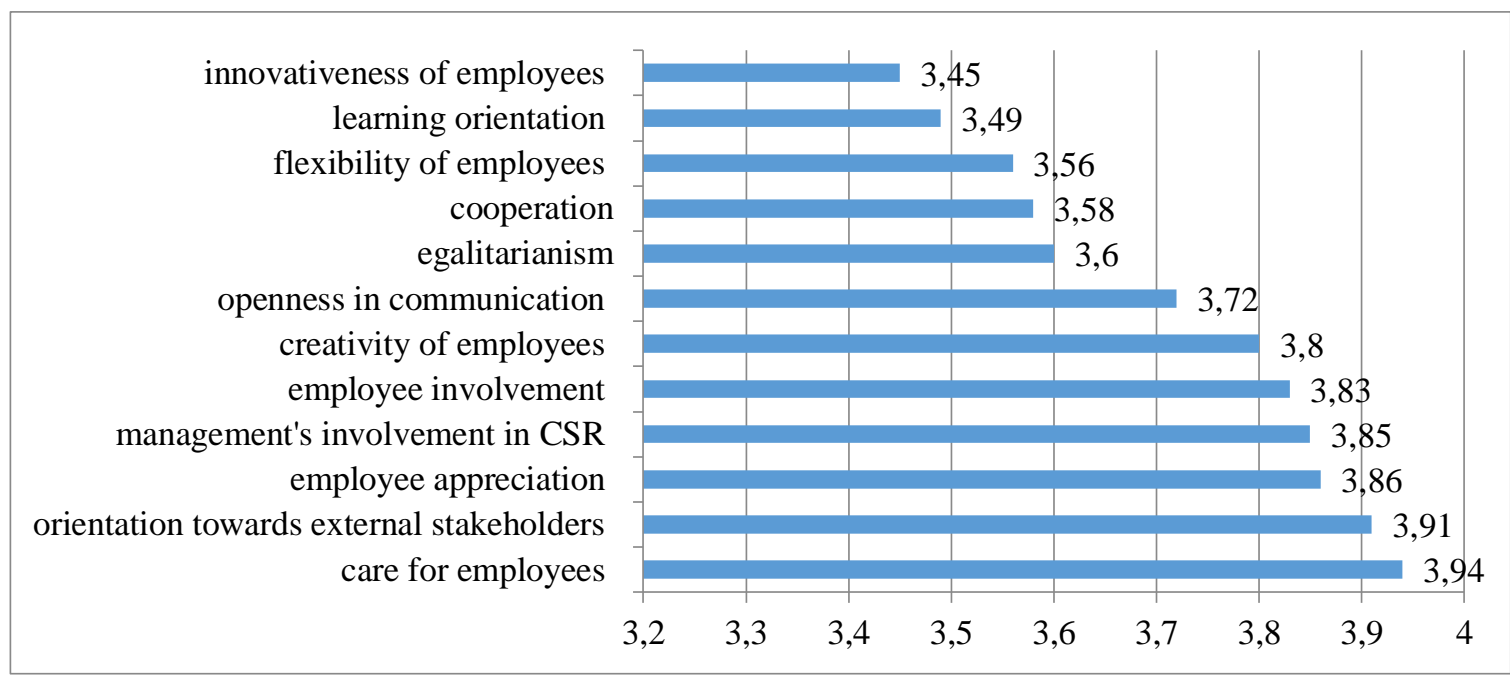

Figure 1. Cultural attitudes conducive to the implementation of CSR - graphic results. Source: own study.

In the case of the cultural attitude - care for employees, the diagnosis was based on several aspects: strategic dimension of employee development, their satisfaction and work-life balance. All of the aforementioned, in the opinion of respondents, can be observed with medium intensity in enterprises. Striving for employee satisfaction through quick and efficient HR department support was most widely perceived by the respondents (4.09). This result corresponds positively to the positive assessment of the actions to create the conditions for maintaining a work-life balance for employees (3.76). However, these actions were less frequently noted than the satisfaction with the support provided by the HR department. Care for employees is anchored in the enterprise's strategy by giving the development of employees a strategic character (3.96).

The orientation on external stakeholders was diagnosed by the importance of contacts with the environment, building lasting relationships with customers and cooperation with them. All the analysed aspects were perceived by the respondents with medium and comparable intensity. In their activity, enterprises treated contacts with the environment as a priority, taking care of good relations with customers, other enterprises and institutions (3.98). In these contacts, they attached particular importance to customers by undertaking systematic actions aimed at building lasting relationships with them (3.97) and cooperation with active users of products or services (3.80).

The diagnosis of the attitude of appreciation of employees included the following aspects: the importance of interpersonal relations, the atmosphere at work, the relation to human resources. The occurrence of two of the analysed aspects was assessed with medium intensity and one with low intensity. Respondents most strongly perceived the actions taken by the management to ensure a good atmosphere at work (4.18). One of the manifestations of caring for a good atmosphere at work was the principles of employment policy. In enterprises, more emphasis is placed on relative stability and development of own human resources. The employment of external staff is a complementary activity (3.78). In this context, 
it is surprising that respondents gave a low rating to the care for interpersonal relations. The emphasis in policies and activities on human and human relationships is perceived with low intensity (3.63).

The involvement of the management in the introduction and implementation of CSR was diagnosed taking into account the inspiring role of the management in creating a climate conducive to CSR, leadership skills as a factor conditioning the implementation of CSR and the competence of the management. Among the analysed aspects, two of them were assessed with medium intensity and one with low intensity. Respondents considered management competence, learning and improvement in the CSR area to be the strongest aspect of their involvement in CSR implementation (4.18). Another dimension of management involvement is their actions to motivate and reward employees. Respondents found that management through these activities creates a climate conducive to CSR (3.77), while leadership skills can be considered a weak determinant of CSR implementation (3.57).

Description of employee involvement included the following aspects: identification of employees with the enterprise, further training in CSR in their free time, strategic dimension of employee involvement in CSR. The respondents observed two of the analysed aspects with medium intensity. One of them concerns the inclusion of the increase in employee involvement in CSR implementation in the enterprise strategy (4.24). This result is one of the highest in the research carried out. This formal way of stimulating involvement could translate into a strong identification of employees with their enterprises (3.86). However, it can be observed that it did not translate into the employees devoting their private time to CSR education. The aspect of employee involvement was assessed by the respondents with a slight intensity (3.41).

The creativity of employees as another analysed cultural attitude was diagnosed using parameters such as employee activity, considering creativity as a CSR impetus and supporting it. The research shows that only conscious actions of the enterprise to support and develop the creativity of its employees are perceived with a medium intensity (4.15), while other aspects of creativity have been defined at a low level. Respondents considered that the activity and talent of employees did not constitute a significant impetus for CSR implementation (3.67), as employees were characterised by displaying little initiative (3.61).

In the case of openness in communication, the diagnosis was based on the following aspects: communicating the importance of CSR to employees, free communication as a factor conditioning the implementation of CSR and the priority of direct conversation in obtaining information. Two of the analysed aspects were perceived with little intensity in the enterprise. This concerns the management's communication to employees on the importance of CSR and its place in the achievement of enterprise objectives (3.58). Also the free communication in the enterprise, which is a prerequisite for effective CSR implementation, was assessed at a low level (3.67). However, this did not result in the respondents perceiving direct conversation as the main way of acquiring and transmitting information (including CSR), at an average level (3.93). 
The diagnosis of egalitarian attitude towards subordinates included several aspects, such as employee co-decision making, autonomy and openness to subordinates. The results of the research showed that one of these is perceived with medium intensity. This includes the openness of supervisors to interaction with their subordinates and the willingness to share information. Respondents described these relations as moderately friendly and empathic (3.87). However, the other two aspects pointing to egalitarianism have been observed with little intensity. The participation of employees in setting objectives and methods of their implementation is small (3.62) and the scope of employees' duties is so detailed that it does not enable them to independently decide on the method of task implementation (3.31).

The description of external and internal cooperation included the following aspects: the enterprise's ability to cooperate externally, the independence of its employees, generation of teams of different composition. The occurrence of two of the analysed aspects was assessed with low intensity and one with medium intensity. The latter result concerned the enterprise's ability to cooperate with external entities, which the respondents assessed as very good (4.07). This corresponds positively to the high rating of the stakeholder orientation. On the other hand, the weak aspects of cooperation are its internal manifestations. Employees are characterised by independence, focus on own needs, limited willingness to cooperate (3.38). This can translate into problems with the creation of teams of different composition (3.29).

The flexibility of employees has been diagnosed taking into account several aspects. These are the ability to respond flexibly, considering changes as an opportunity, stability of rules over time. The results of the research show that all the analysed aspects of flexibility are perceived with low intensity. CSR solutions implemented by the management are not sufficiently flexible in the face of changes occurring in the enterprise and its environment (3.49). Furthermore, change itself is perceived by employees as a threat rather than an opportunity for the enterprise and oneself (3.48). This is due to the lack of top-down tolerance for flexible application of the rules and standards depending on the situation. Therefore, the flexibility of employees' actions is poorly perceived (3.71).

Another analysed attitude was the orientation towards learning diagnosed on the basis of knowledge management implementation, considering training as a CSR impetus, availability of sources of knowledge. All aspects of the learning attitude were assessed with a low intensity. Training and other forms of employee improvement can hardly be treated as an impetus to introduce and implement CSR (3.59). Usually, they were obligatory and the topics did not deepen the CSR issues. The aspect of the learning attitude that is also observed with little intensity is the availability of sources of knowledge of customers and scientific communities for employees (3.63). This result is related to the enterprise's insignificant knowledge management activities (3.30).

The cultural attitude conducive to CSR, which is employee innovation, was diagnosed taking into account its following aspects: the incentive scheme as a factor conditioning innovation, conditions conducive to innovation, innovative dimension of the strategy. 
The intensity of occurrence of each of them was assessed differently. The support of innovative attitudes of employees by the incentive scheme is very small (3.06). This is the lowest score among all the aspects analysed. The conditions for creating innovation are assessed better than the incentive scheme. However, there are very few places created for the free exchange of ideas and improvements (3.32). The above results are surprising due to the adoption of the increase in innovation in the enterprise's strategy, which is observed with a medium intensity. This would mean that, apart from the strategic objective, there are no solutions to support innovation.

\section{Conclusions}

The review of the literature allowed determining cultural attitudes conducive to the implementation of CSR in enterprises. These are: care for employees, appreciation of employees, involvement of management and employees, egalitarianism, creativity, flexibility, innovation of employees, learning orientation, cooperation, openness in communication, focus on external stakeholders.

In enterprises declaring CSR implementation, all cultural attitudes defined as conducive to CSR were verified. This allowed us to confirm that the above-mentioned attitudes exist in enterprises enacting CSR. However, their occurrence is of various intensity. In general, the attitudes analysed were perceived with medium and low intensity. None of the cultural attitudes conducive to CSR were assessed with a high, very high or very low intensity. The lack of strong presence of attitudes is worrying. This means a moderate attitude towards CSR, and thus an average willingness to implement it. Additionally, it should be noted that half of the 12 analysed attitudes were observed with little intensity in enterprises. It can be concluded that cultural attitudes conducive to the implementation of CSR, although they are noticeable in the analysed enterprises, do not provide much support for the implementation of their corporate social responsibility activities.

Among the cultural attitudes that were perceived with medium intensity in enterprises there are: the involvement of management and employees, care and appreciation of employees, focus on stakeholders and creativity of employees. Most of these present the direct attitude of the management towards CSR. The care and appreciation of employees and the focus on stakeholders are the expression of the management's efforts to implement CSR. Considering that it is the attitude of managers that is important in promoting a positive attitude towards CSR, the results of the research obtained may be considered positive for its implementation.

The involvement of managers and employees is partly supported by communication. In the analysed enterprises it has a direct and frequent nature. Managers willingly pass on information to their subordinates in conversations and gather information from them. However, 
internal communication cannot be considered as a factor conditioning CSR in the enterprise. In the opinion of subordinates, the meaning of CSR and its place in the achievement of enterprise objectives is not communicated sufficiently, which may hinder joint involvement of managers and employees in CSR implementation.

Stakeholder orientation is a cultural attitude which, based on the results, can be considered conducive to CSR implementation. Stakeholders are one of the main dimensions of CSR activities. However, the interest is focused mainly on customers. They are a priority in external contacts and cooperation. Actions are taken in enterprises consisting in building lasting relations and cooperating actively with them. This proves that the priority of CSR activities is the achievement of economic objectives by enterprises, and secondarily social and environmental objectives.

The care and appreciation of employees should be considered as a positive result of the research. The activities of the management focusing on the development and creativity of employees, their satisfaction and sense of balance, good atmosphere at work create an environment favourable to CSR. It forms a socially responsible employee who is aware of his or her role as an internal stakeholder building the enterprise's image.

The creativity of employees is an attitude that is contentious in terms of its interpretation. The results of the research indicate that there is a significant support for the creativity of employees on the part of the management. However, the activity of employees in undertaking CSR initiatives is limited and to a small extent their creativity can be considered as an impetus for CSR implementation. It seems that this attitude is being strongly promoted, but not yet practiced. This is all the more so as a few other attitudes related to creativity are hardly perceived. This concerns employees' flexibility, innovation and the willingness to learn, which should be considered as a barrier to CSR implementation. The atmosphere of greater employee involvement to ensure good relations with the business environment is created in organisations where there is focus on learning and acquisition of new competencies awakening the innovative and flexible approach of the employee to the task. In the analysed enterprises these are the least perceived attitudes and it concerns almost every aspect of them. Limited top-down recommendations as to freedom in action, quick response to changes and lack of organisational solutions in the form of incentive system, CSR training, or places for free exchange of ideas are not conducive to developing a creative, flexible and innovative approach to CSR implementation.

The above-mentioned cultural attitudes, which are characterised by low/weak intensity, should be the starting point for activities improving the functioning of the organisation, oriented towards strengthening the intensity of the analysed cultural attitudes. Diagnosing cases of attitudes, identified by the authors, (egalitarianism, employee flexibility, openness in communication, innovation, learning orientation, cooperation orientation) of limited or slight intensity in activities conducive to the implementation of corporate social responsibility by enterprises, is a prelude to a discussion on recommended system solutions. One of the actions, 
which seems necessary, should be the fastest possible implementation by the management of educational solutions (e.g. workshops and training) aimed at raising the level of knowledge of employees in the field of communication, learning and cooperation. Education in this area may be helpful not only in raising the level of knowledge, but also in eliminating the uncertainty of employees about changes in the scope of a CSR-oriented enterprise. Another recommended action in solving the diagnosed low intensity of attitudes should be the introduction of organisational solutions aimed at increasing employee motivation which, when properly applied, could be reflected in increased flexibility of employees' actions, better attitude towards cooperation and learning or their participation in setting goals. Inadequately constructed incentive scheme or mistakes in the area of motivation activities may be a reason to the continuation of research in this context by the authors in further research work.

The research results obtained cannot be generalised. They are based on a purposive sample of Polish enterprises declaring CSR implementation. However, they bring new knowledge about CSR and cultural attitudes. They can be used by managers to shape attitudes conducive to CSR. Further research could include other cultural attitudes and the number of aspects diagnosing individual attitudes could be increased. An interesting research thread would concern the inclusion of industry and the form of ownership as variables differentiating cultural attitudes conducive to the implementation of CSR. The international dimension could also be taken into account by comparing research findings on attitudes towards CSR in different countries.

\section{References}

1. Adamczyk, J. (2009). Społeczna odpowiedzialność przedsiębiorstw. Warszawa: PWE.

2. Albertini, E. (2015). Relationships between CSR and Intellectual Capital: The CEOs point of view. Conference Paper EURAM - European Academy of Management, Warsaw.

3. Bartkowiak, G. (2011). Społeczna odpowiedzialność biznesu w aspekcie teoretycznym i empirycznym. Warszawa: Difin.

4. Bartkowiak, P., Dudek, D., Wszendybyk-Skulska, E. (2016). Koncepcja społecznej odpowiedzialności $i$ koncepcja zrównoważonego rozwoju $w$ procesie funkcjonowania organizacji. Kraków: Wydawnictwo Uniwersytetu Jagiellońskiego.

5. Bednarska-Olejniczak, D. (2017). Edukacja finansowa jako przejaw społecznej odpowiedzialności banków. e-mentor, 5(72), 42-47.

6. Bem, K. (2008). Programy społecznej odpowiedzialności biznesu jako element strategii przedsiębiorstwa. Annales. Etyka wżyciu gospodarczym, 11, 1, 171-179.

7. Borkowska, S. (2005). CSR - wyzwaniem dla zarządzania zasobami ludzkimi - podejście unijne. Zarzadzanie Zasobami Ludzkimi, 6, 9-29. 
8. Bowen, H.R. (1953). Social Responsibilities of the businessman. New York: Harper \& Row.

9. Branco, M., Rodrigues, L. (2006). Corporate Social Responsibility and Resource-Based Perspectives. Journal of Business Ethics, 69(2), 111-132. DOI 10.1007/s.10551-006-9071-z.

10. Caroll, A.B. (1979). A three-dimensional conceptual model of corporate social performance. Academy of Management Review, 4(4), 497-505.

11. Chandler, D. (2014). Corporate social responsibility: A strategic perspective. Business Expert Press.

12. Ciechan-Kujawa, M. (2013). Zakres ujawnień kosztów i źródeł finansowania inicjatyw odpowiedzialnych społecznie w świetle raportów CSR. Zeszyty Naukowe Gtównej Szkoły Handlowej, 129, 85-96.

13. Collier, J., \& Esteban, R. (2007). Corporate social responsibility and employee commitment. Business Ethics: A European Review, 16(1), 19-33.

14. De Lacerda, T.M. (2010). Transformational Leadership Effectiveness in Implementing Corporate Social Responsibility Strategies: An Empirical study of the Largest Firm in Portugal. Social Responsibility Journal, 7(6), 370-389.

15. Doktór, K. (2005). Dylematy społecznej odpowiedzialności organizacji gospodarczych. Zarzadzanie zasobami ludzkimi, 6, 31-46.

16. Du S., Swaen V., Lindgreen A, Sen S. (2013). The Roles of Leadership Styles in Corporate social Responsibility. Journal of Business Ethics, 114, 155-169. DOI.org/10.1007/s10551012-1333-3.

17. Ejdys, J., Gulc, A. (2015). Koncepcja społecznej odpowiedzialności narzędziem poprawy innowacyjności przedsiębiorstw sektora MŚP. Prace Naukowe Uniwersytetu Ekonomicznego we Wrocławiu, 378, 103-115. DOI: 10.15611/pn.2015.378.08.

18. Filek, J. (2008). Przyczyny małego zainteresowania ideą CSR w Polsce. In: M. Bąk, P. Kulawczuk (Eds.), Społeczna Odpowiedzialność Biznesu $w$ matych i średnich przedsiębiorstwach. Warszawa: Wydawnictwo Instytut Badań nad Demokracją i Przedsiębiorstwem Prywatnym.

19. Galbreath, J. (2010). Drivers of Corporate Social Responsibility: the Role of Formal Strategic Planning and Firm Culture. British Journal of Management, 21(2), 511-525.

20. Ganescu, C., Gangone, A. (2017). A model of Socially Responsible Organizational Culture. Studia Universitatis VasileGoldis Arad, 27, 2, 45-59.

21. Gazzola, P., Colombo, G. (2014). CSR Integration into the Corporate Strategy. CrossCultural Management Journal, XVI, 2, 331-338.

22. Geryk, M. (2012). Społeczna odpowiedzialność uczelni. Warszawa: Oficyna Wydawnicza SGH.

23. Griffin, R.W., Ebert R.J. (2006). Business. Upper Saddle River: Pearson Prentice Hall.

24. Grovess, K.S., Larocca, M.A. (2011). An Empirical Study of Leader Ethical Values, Transformational and Transactional Leadership, and Follower Attitudes toward Corporate Social Responsibility. Journal of Business Ethics, 103(4), 511-528. 
25. Hilgard, E.R. (1971). Wprowadzenie do psychologii. Warszawa: PWN.

26. Jaakson, K., Vadi, M., Tamm, K. (2009). Organizational culture and CSR: An exploratory study of Estonian service organizations, Social Responsubility Journal, 5, 1, 6-18. DOI: $10.1108 / 1747111091093992$.

27. Kaźmierczak, M. (2015). CSR a budowanie kapitału społecznego organizacji. Prace Naukowe Uniwersytetu Ekonomicznego we Wrocławiu, 378, 146-157.

28. Kaźmierczak, M. (2017). Determinanty zarzadzania społecznie odpowiedzialnego w sektorze małych i średnich przedsiębiorstw. Poznań: Wydawnictwo UEP.

29. Klimkiewicz, K. (2011). Społeczna odpowiedzialność przedsiębiorstwa jako wyraz kultury organizacyjnej, In: Z. Pisz, M. Rojek-Nowosielska (Ed.), Społeczna odpowiedzialność organizacji. Metodyka, narzędzia, ocena. Wrocław: Wydawnictwo Uniwersytetu Ekonomicznego.

30. Kotler, P., Lee, N. (2005). Corporate Social Responsibility. Doing the Most Goodfor Your Company and Your Cause. Hoboken: John Wiley \& Sons.

31. Koźmiński, A.K., Jemielniak, D. (2008). Zarzadzanie od podstaw. Podręcznik akademicki. Warszawa: Wydawnictwa Akademickie i Profesjonalne.

32. Kuraszko, I., Rok, B. (2007). Społeczna odpowiedzialność biznesu i ekonomia społeczna. Ekonomia Społeczna. Teksty, 7, 1-20.

33. Malara, Z., Kroik, J. (2012). Społeczna odpowiedzialność przedsiębiorstwa konstytuowanie koncepcji w perspektywie strategicznej. Organizacja $i$ Kierowanie, 1, 11-22.

34. Mohelska, H., Sokolova, M. (2017). Innovative Culture of the Organization and Its Role in the Concept of Corporate Social Responsibility Czech Republic Case Study. Amfiteatru Economic, 19(46), 853-865.

35. Morsing, M. (2006). Corporate Social Responsibility as strategic auto-communication: On the role of external stakeholders for member identification. Business Ethics: A European Review, 15, 2, 171-182.

36. Pedersen, E.R.G., Gwozdz, W., Hvass, K. (2018). Exploring the Relationship between Business Model Innovation, Corporate Sustainability, and Organizational Values within the Fashion Industry. Journal of Business Ethics, 149, 2, 267-284.

37. Ratajczak, M., Wołoszyn, J., Stawicka, E. (2012). Koncepcja CSR w aspekcie pracowników na przykładzie przedsiębiorstw agrobiznesu z województwa mazowieckiego. In: J. Sokołowski, M. Sosnowski, A. Żabiński (Ed.), Polityka ekonomiczna. Wrocław: Wydawnictwo Uniwersytetu Wrocławskiego.

38. Rozkwitalska, M. (2006). Kultura organizacyjna korporacji transnarodowych oparta o społeczną odpowiedzialność. Organizacja i Kierowanie, 2, 33-50.

39. Rudnicka, A. (2012). CSR - doskonalenie relacji społecznych w firmie. Warszawa: Wydawnictwo Wolters Kluwer. 
40. Slack, R., Corlett, S., Morris, R. (2015). Exploring employee engagement with (corporate) social responsibility: A Social Exchange perspective on organisational participation. Journal of Business Ethics, 127(3), 537-548. DOI.org/10.1007/s10551-014-2057-3.

41. Vitolla, F., Rubino, M., Garzoni, A. (2017). The integration of CSR into strategic management: a dynamic approach based on social management philosophy. Corporate Governance. The International Journal of Business in Society, 17, 1, 89-116.

42. Walkowiak, R. (2009). Kultura organizacyjna jako determinanta działań społecznie odpowiedzialnych. In: M. Juchnowicz (Ed.), Kulturowe uwarunkowania zarzadzania kapitałem ludzkim. Kraków: Wolters Kluwer.

43. Wilewska, M. (2011). Percepcja społecznej odpowiedzialności biznesu - źródła kontrowersji i dylematy związane z jej urzeczywistnieniem. In: Z. Pisz, M. RojekNowosielska (Ed.), Społeczna odpowiedzialność organizacji. Metodyka, narzędzia, ocena. Wrocław: Wydawnictwo Uniwersytetu Ekonomicznego.

44. Wolniak, R. (2015). Dystans wobec władzy według typologii Hofstedego a implikacja koncepcji społecznej odpowiedzialności biznesu w organizacjach. Zeszyty Naukowe Politechniki Śląskiej, 82, 343-357.

45. Wołczek, P. (2011). Strategia a CSR. In: Z. Pisz, M. Rojek-Nowosielska (Ed.), Społeczna odpowiedzialność organizacji. Metodyka, narzędzia, ocena. Wrocław: Wydawnictwo Uniwersytetu Ekonomicznego.

46. Wołoszyn, J., Ratajczak, M. (2010). Społeczna odpowiedzialność przedsiębiorstw wobec oczekiwań interesariuszy. Zeszyty Naukowe Szkoły Głównej Gospodarstwa Wiejskiego, 83, 95-102.

47. Zieliński, M. (2015). Profitability of CSR from the perspective of HRM. Organizacja i Zarzadzanie, 81, 155-165.

48. Zimbardo, P.G., Leippe, M.R. (2004). Psychologia zmiany postaw i wpływu społecznego. Poznań: Wydawnictwo Zysk i S-ka.

49. Żemigała, M. (2007). Społeczna odpowiedzialność przedsiębiorstwa. Budowanie zdrowej, efektywnej organizacji. Kraków: Oficyna Wolters Kluwer Business. 